\title{
ESTIMATES OF THE PREVALENCE OF RHEUMATIC DISEASES IN THE POPULATION OF TECUMSEH, MICHIGAN, 1959-60*
}

\author{
William M. Mikkelsen, M.D., Horace J. Dodge, M.D., Ivan F. DufF, M.D. \\ and Hiroo Kato, M.D.
}

\begin{abstract}
Department of Epidemiology, School of Public Health, and the Department of Internal Medicinc, Medical School, The University of Michigan
\end{abstract}

(Received 12 October 1966; in revised form 1 February 1967)

The Tecumsen Community Health Study (TCHS) was not undertaken solely as a rheumatic disease survey but as a broad study of health and disease in a total community setting. $[1,2]$ It was conceived as a continuing dynamic study of the multitude of natural processes and interactions which are responsible for the maintenance of health or the development of disease. Interest has centered not so much on the identification of established disease as on the possibility of elucidating the early origins of disease and identifying those apparently healthy individuals with a predisposition to disease. The focus has been on the family unit and kindred since the working hypothesis has been that if genetic or environmental factors are operative in the production of a given disease then actual or potential viotims should cluster about the identifiable index cases.

After careful study the community of Tecumseh, Michigan was selected as the site of the study in 1957. Tecumseh is located in southeastern Michigan approximately 30 miles from Ann Arbor. Its size of $\mathbf{9 5 0 0}$ was considered adequate and yet small enough to make an ambitious study practicable. It is located in a rural agricultural area but also has a large manufacturing plant so that a variety of socioeconomic groups are present. Available information indicated the relative stability of the population and a friendly cooperative community spirit was apparent.

In 1957 a complete census of the town was undertaken and all inhabitants charted by households and kindreds. Self-reported information was obtained regarding forty chronic health conditions including "arthritis", "rheumatism" and chronic back pain. During 1957 and 1958 several pilot studies, including an investigation of cerebral palsy, a prophylactic trial of influenza vaccine and a study of the relationship between blood groups and fertility, were successfully concluded.

\section{METHODS OF STUDY}

The present phase of the study was designed to obtain medical historical information, a physical examination and certain physical and laboratory measurements

\footnotetext{
*This study is reported for the Research Staff of the Cardiovascular Research Center and the Tecumseh Community Health Study, The University of Michigan, Ann Arbor. The study was supported by grants from the U.S. Public Health Service: Grant CD-00005, Program Project Grant H-6378 from the National Heart Institute, and Training Grant GM-6 from the National Institute of General Medical Sciences.
} 
on all residents of the community. The initial contact was made in the home by specially trained lay interviewers. With the aid of a detailed medical questionnaire, information was obtained regarding the respondent's present state of health and past and family medical history. Specific inquiry was made regarding past or present joint pain, joint swelling, morning stiffness and a history of "arthritis" or "rheumatism". An appointment was then made for the entire family to attend an examination clinic established in the community hospital. This clinic was staffed by physicians from the School of Public Health and Medical School of The University of Michigan.

After reviewing and augmenting the medical history the examining physician performed a detailed physical examination including evaluation of the spine and peripheral joints. Blood and urine specimens were obtained. Blood chemical determinations included hemoglobin, glucose, cholesterol and uric acid concentrations and the latex fixation test for rheumatoid arthritis. Uric acid determinations were made by the enzymatic spectrophotometric method of LidDif, SEFGMILler and LASTER. [3] The latex fixation tests were performed by the technique of SINGER and PLOTz [4] agglutination in a dilution of $1: 20$ or greater was considered a positive test. The clinic nurse obtained a number of anthropometric measurements and a 12-lead electrocardiogram. An anteroposterior chest X-ray examination was obtained but X-rays of the spine and peripheral joints were not included in this phase of the study. In most instances respondents spent not more than $1 \frac{1}{2} \mathrm{hr}$ in the examination clinic. The clinic operated 6 days weekly, approximately 25-30 respondents being examined at each session. The examinations were performed during the period from February 1959 to October 1960. Of 9794 persons of all ages in the study area, 88 per cent participated by providing historical information and submitting to examination. Of those $6 \mathrm{yr}$ of age or older, 87 per cent or 7207 persons participated. The age and sex distribution of the 7207 respondents age 6 or over is given in Fig. 1. Some of the data pertaining to rheumatic complaints and the diagnosis of rheumatoid arthritis have previously been presented in part. [8]

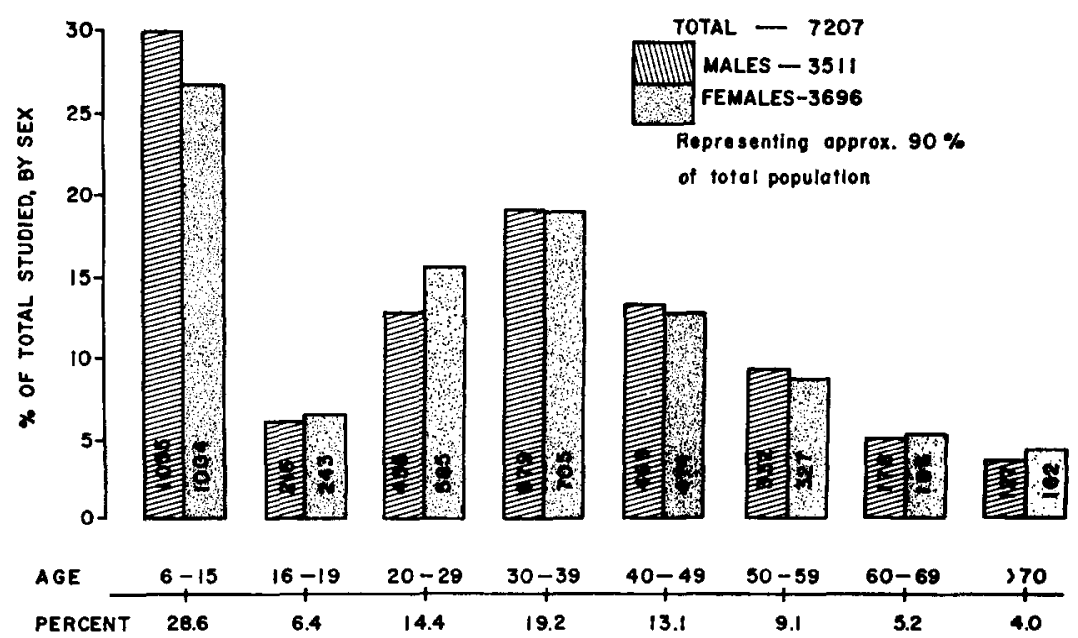

FIG. 1. Age distribution of population studied age 6 and over. 


\section{RESULTS}

\section{Historical information}

The prevalence rates for positive replies to the questions regarding rheumatic diseases were quite similar for the two sexes (Table 1). Approximately one-third of both male and female respondents age $6 \mathrm{yr}$ and over gave a history of joint pain or aching. Joint swelling, morning stiffness and a history of arthritis or rheumatism were reported less frequently (13-20 per cent) and were somewhat more prevalent in females. Joint pain and swelling were more frequently attributed to arthritis by the female respondents, whereas the male respondents more often attributed them to accident or injury. Approximately half of the subjects reporting morning stiffness stated that it was of 30 min or greater duration.

TABLE 1. SEX SPECIFIC FREQUENCY (\%) OF REPLIES to FOUR SCREENING QUESTIONS CONCERNING JOINT SYMPTOMS

\begin{tabular}{lcc}
\hline Question & \multicolumn{2}{c}{ Respondents } \\
\cline { 3 - 3 } Reply & Male (\%) & Female (\%) \\
\hline 1. Pain or aching in joints? & 34.4 & 34.8 \\
a. All "yes" answers & 8.7 & 14.8 \\
b. "Yes" attributed to arthritis & 13.4 & 16.9 \\
2. Joint swelling? & 2.9 & 8.1 \\
a. All "yes" answers & 15.7 & 19.5 \\
b. "Yes" attributed to arthritis & 13.3 & 19.2 \\
3. Morning stiffness? & & \\
4. Ever had arthritis or rheumatism? & & \\
\hline
\end{tabular}

The age-sex specific prevalence rates for each of these four historical items (Figs. 2-5) rose with increasing age. Male and female rates tended to be quite similar during the first four decades of life, but female rates were thereafter some-

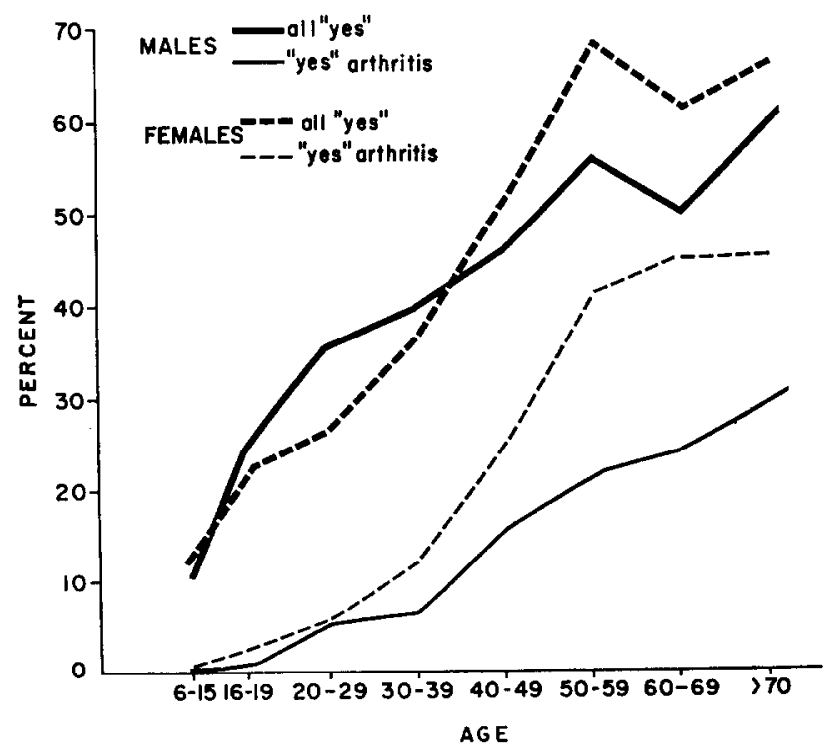

Fig. 2. History of joint pain or aching. 


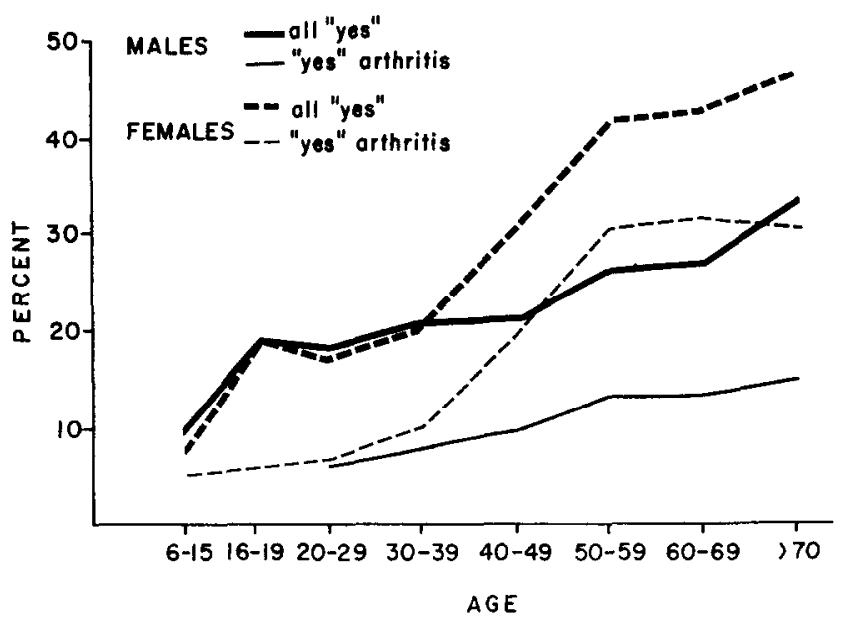

FIG. 3. History of joint swelling.

what higher. Prevalence rates for joint pain, joint swelling and morning stiffness appeared to level off in the later decades of life, while that for arthritis and rheumatism continued to rise.

\section{Latex fixation tests}

The age-sex specific prevalence rates for positive latex fixation tests are shown in Table 2 and Fig. 6. Positive tests occurred with equal frequency in male and female respondents, 3.4 and 3.3 per cent respectively. The rates rise progressively from about 1 per cent in the 6-16 yr age group to almost 14 per cent for males and 9.4 per cent for females in the oldest age groups. The distribution of positive results by titer was quite similar in both sexes, approximately one-third having a titer of 1 to 5120 or greater; tests were not carried beyond this dilution.

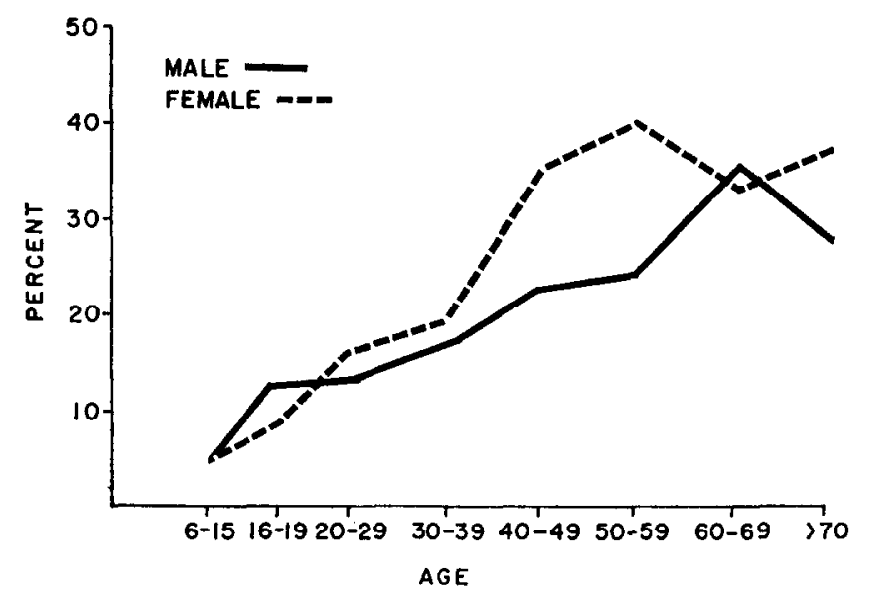

FIG. 4. History of morning stiffness. 


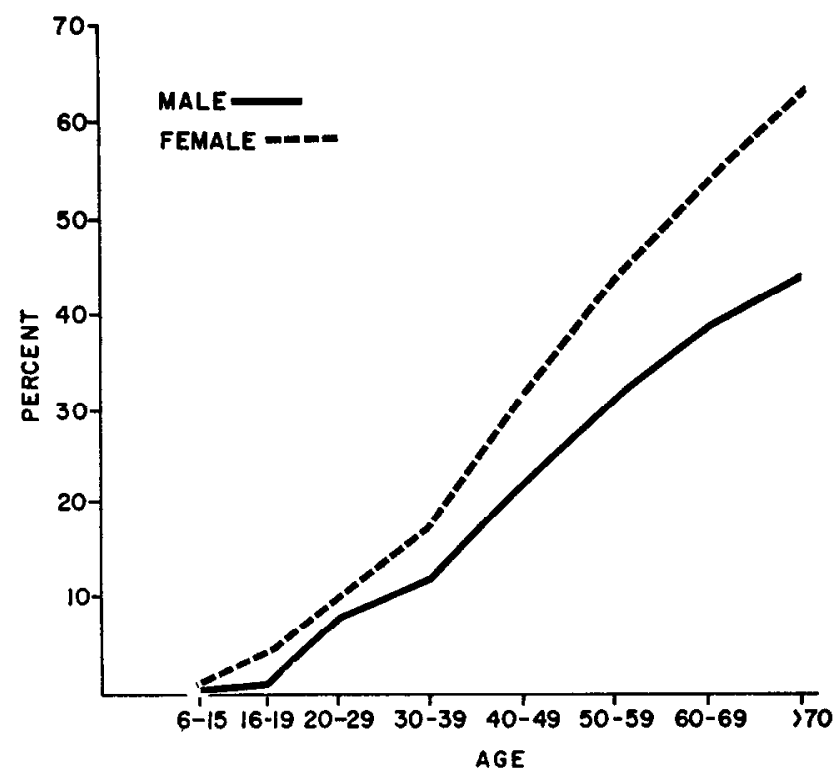

FIG. 5. History of arthritis or rheumatism.

Table 2. Age-SEX SPECific PREVAlenCe of Positive Latex fixation tests

\begin{tabular}{lcccccc}
\hline Age & \multicolumn{2}{c}{ Males } & \multicolumn{2}{c}{ Females } & \multicolumn{2}{c}{ Both sexes } \\
\cline { 2 - 7 } $\begin{array}{c}\text { Group } \\
\text { in yr }\end{array}$ & $\begin{array}{c}\text { Number } \\
\text { tested }\end{array}$ & $\begin{array}{c}\% \\
\text { positive }\end{array}$ & $\begin{array}{c}\text { Number } \\
\text { tested }\end{array}$ & $\begin{array}{c}\% \\
\text { positive }\end{array}$ & $\begin{array}{c}\text { Number } \\
\text { tested }\end{array}$ & $\begin{array}{c}\% \\
\text { positive }\end{array}$ \\
\hline $6-15$ & 875 & 0.8 & 753 & 1.3 & 1628 & 1.0 \\
$16-19$ & 213 & 1.4 & 217 & 1.4 & 430 & 1.4 \\
$20-29$ & 445 & 2.0 & 550 & 2.0 & 995 & 2.0 \\
$30-39$ & 670 & 3.3 & 678 & 3.8 & 1348 & 3.6 \\
$40-49$ & 462 & 3.9 & 460 & 3.0 & 922 & 3.5 \\
$50-59$ & 323 & 8.0 & 313 & 4.5 & 636 & 5.3 \\
$60-69$ & 175 & 4.1 & 184 & 9.8 & 359 & 7.5 \\
$70+$ & 124 & 13.7 & 148 & 9.4 & 272 & 11.4 \\
\hline All ages & 3287 & 3.4 & 3303 & 3.3 & 6590 & 3.35 \\
\hline
\end{tabular}

The association between positive latex fixation tests and the clinical diagnosis of rheumatoid arthritis is shown in Table 3. It will be noted that of the 399 respondents with historical or physical findings raising a suspicion of rheumatoid arthritis only 74 or 18 per cent had a positive latex test. Of those fulfilling the A.R.A. criteria for "definite" rheumatoid arthritis, 26 per cent had a positive latex test. Of the 221 respondents with a positive latex test, 66 per cent had no other reason for suspicion of rheumatoid arthritis.

The prevalence of positive latex fixation tests in respondents with certain other diagnoses is given in Table 4. Individuals with a history of infectious hepatitis or of unspecified jaundice had a relatively high rate of latex positivity, as did those with evidence of emphysema or right heart failure. Of the relatively small number 


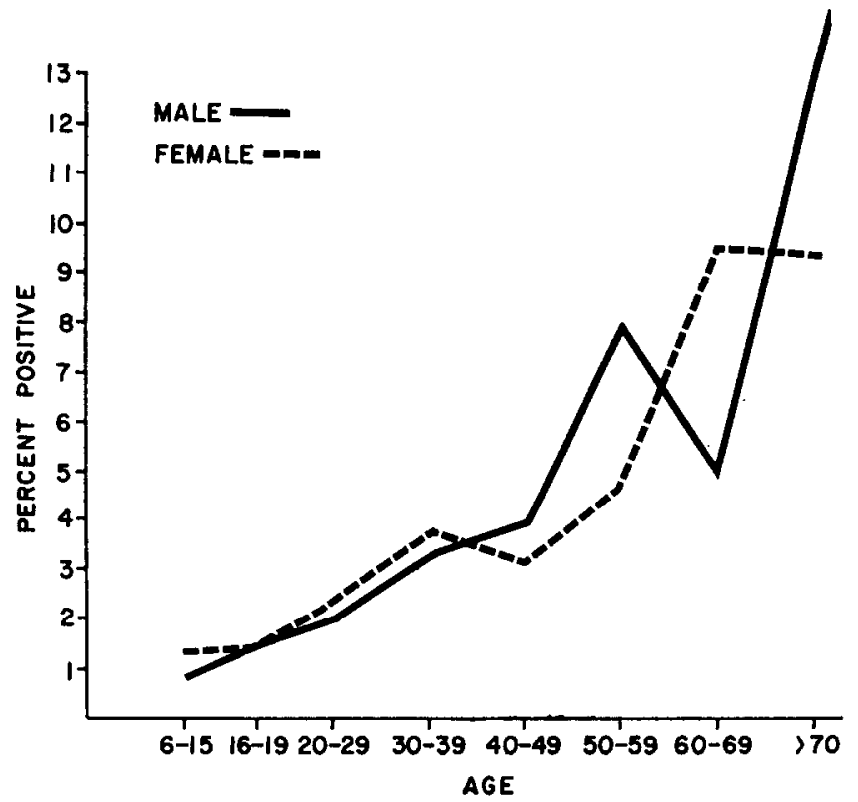

Fig. 6. Latex fixation test results.

TABLE 3. THE ASSOCIATION BETWEEN POSITTVE LATEX FIXATION TESTS AND THE CLINICAL DIAGNOSIS OF RHEUMATOID ARTHRITIS

\begin{tabular}{|c|c|c|c|}
\hline \multirow{2}{*}{$\begin{array}{l}\text { Diagnosis of } \\
\text { rheumatoid } \\
\text { arthritis }\end{array}$} & \multicolumn{2}{|c|}{ Latex fixation test } & \multirow[t]{2}{*}{ Total } \\
\hline & Positive & Negative & \\
\hline Suspected & $\begin{array}{l}\mathrm{a} \\
\quad 74 \\
\\
\end{array}$ & ${ }^{b_{25}}$ & $\begin{array}{l}\mathrm{a}+\mathrm{b} \\
399 \\
\quad(6.0)\end{array}$ \\
\hline Not suspected & $\begin{array}{l}\mathrm{c}_{147} \\
{ }_{(2.2)}\end{array}$ & $\begin{array}{l}d \\
6044 \\
\quad(91.7)\end{array}$ & $\begin{array}{l}c+d \\
6191 \\
\end{array}$ \\
\hline Total & $\begin{array}{c}a+c \\
221 \\
\text { (3.3) }\end{array}$ & $\begin{array}{l}b+d \\
6369 \\
(96.6)\end{array}$ & $\begin{array}{c}a+b+c+d \\
6590 \\
(99.9)\end{array}$ \\
\hline
\end{tabular}

( ) = number in the cell as per cent of total examined.

Sensitivity of L.F. test $=a / a+b=74 / 399=18.5 \%$.

Specificity of L.F. test $=d / c+d=6044 / 6191=97.6 \%$.

of subjects with psoriasis or with pregnancy at the time of examination, none had positive results. The prevalence of latex test positivity was related to blood pressure, serum uric acid and serum cholesterol concentrations (Tables 5 and 6). Because the prevalence rises with age, age specific rates were computed for persons $16 \mathrm{yr}$ of age and older; blood pressures were not recorded nor were cholesterol determinations done for persons under $16 \mathrm{yr}$ of age. 
Table 4. Prevalence (\%) of positive latex fixation tests in relation to the degree of CERTAINTY OF DIAGNOSIS OF SELECTED CONDITIONS

\begin{tabular}{|c|c|c|c|c|c|c|}
\hline \multirow[b]{3}{*}{ Condition } & \multirow{2}{*}{\multicolumn{2}{|c|}{ Condition absent }} & \multicolumn{4}{|c|}{ Condition diagnosed as: } \\
\hline & & & \multicolumn{2}{|c|}{ Possible } & \multicolumn{2}{|c|}{ Probable } \\
\hline & $\begin{array}{l}\text { No. of } \\
\text { persons }\end{array}$ & $\begin{array}{l}\text { \% with } \\
\text { positive } \\
\text { L.F. test }\end{array}$ & $\begin{array}{l}\text { No. of } \\
\text { persons }\end{array}$ & $\begin{array}{l}\% \text { with } \\
\text { positive } \\
\text { L.F. test }\end{array}$ & $\begin{array}{l}\text { No. of } \\
\text { persons }\end{array}$ & $\begin{array}{l}\% \text { with } \\
\text { positive } \\
\text { L.F. test }\end{array}$ \\
\hline Jaundice, unspecified & 4921 & 3.8 & 82 & 1.2 & 125 & 11.2 \\
\hline Infectious hepatitis & 4801 & 3.9 & 178 & 3.4 & 149 & 8.0 \\
\hline Emphysema & 4851 & 3.6 & 153 & 7.8 & 124 & 9.7 \\
\hline Right heart failure & 5058 & 3.8 & 49 & 14.3 & 21 & 9.5 \\
\hline Peptic ulcer & 4597 & 4.0 & 340 & 2.4 & 191 & 5.2 \\
\hline Rheumatic fever & 4854 & 3.9 & 215 & 3.7 & 59 & 5.1 \\
\hline Diabetes, history & 4089 & 3.8 & 803 & 4.2 & 236 & 4.7 \\
\hline Psychoneurosis & 4344 & 4.0 & 453 & 3.1 & 331 & 3.9 \\
\hline Hayfever & 4562 & 3.9 & 192 & 3.6 & 374 & 3.7 \\
\hline Asthma & 4624 & 3.9 & 261 & 4.6 & 243 & 3.7 \\
\hline Pulm. tuberculosis & 4973 & 3.9 & 109 & 2.8 & 46 & 2.2 \\
\hline Pregnancy & 5036 & 4.0 & 23 & 0.0 & 69 & 0.0 \\
\hline Psoriasis & 5073 & 3.9 & 28 & 7.1 & 27 & 0.0 \\
\hline
\end{tabular}

Table 5. Age specific prevalence (\%) of positive latex fiXation tests in relation to SYSTOLIC AND DIASTOLIC BLOOD PRESSURE LEVELS

\begin{tabular}{|c|c|c|c|c|c|}
\hline \multirow{2}{*}{\multicolumn{2}{|c|}{$\begin{array}{c}\text { Blood pressure } \\
(\mathrm{mm} \text { of } \mathrm{Hg})\end{array}$}} & \multicolumn{3}{|c|}{ Age in $\mathrm{yr}$} & \multirow[t]{2}{*}{ Total } \\
\hline & & $16-29$ & $30-49$ & 50 or more & \\
\hline \multicolumn{6}{|l|}{ Systolic } \\
\hline \multirow{3}{*}{ Less than 140} & (a) & 1086 & 1346 & 376 & 2808 \\
\hline & (b) & 46 & 43 & 26 & 115 \\
\hline & (c) & 4.2 & 3.2 & 6.9 & 4.1 \\
\hline \multirow{3}{*}{$140-159$} & (a) & 202 & 502 & 372 & 1076 \\
\hline & (b) & 7 & 19 & 28 & 54 \\
\hline & (c) & 3.2 & 3.8 & 7.5 & 5.0 \\
\hline \multirow{3}{*}{160 or more } & (a) & 48 & 207 & 367 & 622 \\
\hline & (b) & 0 & 12 & 32 & 44 \\
\hline & (c) & 0.0 & 5.8 & 8.7 & 7.1 \\
\hline \multirow[t]{3}{*}{ Total } & (a) & 1336 & 2055 & 1115 & 4506 \\
\hline & (b) & 53 & 74 & 86 & 213 \\
\hline & (c) & 4.0 & 3.6 & 7.7 & 4.7 \\
\hline \multicolumn{6}{|l|}{ Diastolic (V phase) } \\
\hline & (a) & 1208 & 1478 & 623 & 3309 \\
\hline \multirow[t]{2}{*}{ Less than 90} & (b) & 51 & 53 & 41 & 145 \\
\hline & (c) & 4.2 & 3.6 & 6.6 & 4.4 \\
\hline \multirow{3}{*}{$90-94$} & (a) & 78 & 281 & 199 & 558 \\
\hline & (b) & 1 & 11 & 23 & 35 \\
\hline & (c) & 1.3 & 3.9 & 11.6 & 6.3 \\
\hline \multirow{3}{*}{95 or more } & (a) & 50 & 296 & 293 & 639 \\
\hline & (b) & 1 & 10 & 22 & 33 \\
\hline & (c) & 2.0 & 3.4 & 7.5 & 5.2 \\
\hline \multirow[t]{3}{*}{ Total } & (a) & 1336 & 2055 & 1115 & 4506 \\
\hline & (b) & 53 & 74 & 86 & 213 \\
\hline & (c) & 4.0 & 3.6 & 7.7 & 4.7 \\
\hline
\end{tabular}

Numbers in each cell are as follows:

(a) Number of persons examined for whom both blood pressures were recorded and a latex fixation test reported.

(b) Number of persons with a positive L.F. test.

(c) Prevalence $(\%)$ of positive L.F. tests in those examined. 
Table 6. Age specific prevalence (\%) of positive latex fixation tests in relation to CONCENTRATIONS OF SERUM URIC ACID AND OF SERUM CHOLESTEROL

\begin{tabular}{|c|c|c|c|c|c|}
\hline \multirow{2}{*}{$\begin{array}{l}\text { Concentration } \\
(\mathrm{mg} \text { per } 100 \mathrm{ml})\end{array}$} & & \multicolumn{3}{|c|}{ Age in $y r$} & \multirow[b]{2}{*}{ Total } \\
\hline & & $16-29$ & $30-49$ & 50 or more & \\
\hline \multicolumn{6}{|l|}{ Serum uric acid } \\
\hline & (a) & 128 & 156 & 58 & 342 \\
\hline \multirow[t]{2}{*}{ Less than 3.0} & (b) & 1 & 3 & 4 & 8 \\
\hline & (c) & 0.8 & 1.9 & 6.9 & 2.3 \\
\hline \multirow{3}{*}{$3.0-3.9$} & (a) & 383 & 491 & 192 & 1066 \\
\hline & (b) & 7 & 16 & 20 & 43 \\
\hline & (c) & 1.8 & 3.3 & 10.4 & 4.0 \\
\hline \multirow{3}{*}{$4.0-4.9$} & (a) & 462 & 584 & 328 & 1374 \\
\hline & (b) & 7 & 23 & 21 & 51 \\
\hline & (c) & 1.5 & 3.9 & 6.4 & 3.7 \\
\hline \multirow{3}{*}{$5.0-5.9$} & (a) & 349 & 446 & 310 & 1105 \\
\hline & (b) & 6 & 12 & 24 & 42 \\
\hline & (c) & 1.7 & 2.8 & 7.7 & 3.8 \\
\hline \multirow{3}{*}{$6.0-6.9$} & (a) & 165 & 199 & 152 & 516 \\
\hline & (b) & 3 & 10 & 9 & 22 \\
\hline & (c) & 1.8 & 5.0 & 5.9 & 4.3 \\
\hline \multirow{3}{*}{7.0 or more } & (a) & 80 & 104 & 90 & 274 \\
\hline & (b) & 1 & 4 & 7 & 12 \\
\hline & (c) & 1.2 & 3.8 & 7.8 & 4.8 \\
\hline \multirow[t]{3}{*}{ Total } & (a) & 1567 & 1980 & 1130 & 4677 \\
\hline & (b) & 25 & 68 & 85 & 178 \\
\hline & (c) & 1.6 & 3.4 & 7.5 & 3.8 \\
\hline \multicolumn{6}{|l|}{ Serum cholesterol } \\
\hline \multirow{3}{*}{ Less than 150} & (a) & 229 & 77 & 23 & 329 \\
\hline & (b) & 4 & 6 & 2 & 12 \\
\hline & (c) & 1.7 & 7.8 & 8.7 & 3.6 \\
\hline \multirow{3}{*}{$150-199$} & (a) & 779 & 768 & 231 & 1778 \\
\hline & (b) & 15 & 33 & 26 & 74 \\
\hline & (c) & 1.9 & 4.3 & 11.3 & 4.2 \\
\hline \multirow{3}{*}{$200-249$} & (a) & 341 & 1000 & 514 & 1885 \\
\hline & (b) & 5 & 22 & 34 & 61 \\
\hline & (c) & 1.5 & 2.2 & 6.6 & 3.2 \\
\hline \multirow{3}{*}{$250-299$} & (a) & 55 & 338 & 372 & 765 \\
\hline & (b) & 1 & 15 & 26 & 42 \\
\hline & (c) & 1.8 & 4.4 & 7.0 & 5.5 \\
\hline \multirow{3}{*}{300 or more } & (a) & 17 & 77 & 117 & 211 \\
\hline & (b) & 0 & 4 & 6 & 10 \\
\hline & (c) & 0.0 & 4.4 & 5.1 & 4.7 \\
\hline \multirow[t]{3}{*}{ Total } & (a) & 1421 & 2260 & 1257 & 4938 \\
\hline & (b) & 25 & 80 & 94 & 199 \\
\hline & (c) & 1.8 & 3.5 & 7.5 & 4.0 \\
\hline
\end{tabular}

Numbers in each cell are as follows:

(a) Number of persons examined whom both a latex fixation test and the specific biochemical procedure were reported.

(b) Number of persons with a positive L.F. test.

(c) Prevalence (\%) of positive L.F. tests in those examined. 
Table 5 shows a slight increase in prevalence rates with increasing systolic pressure levels, but only in persons $30 \mathrm{yr}$ of age or older. There is no apparent association of latex positivity with diastolic pressure as classified here. When blood pressures are cross classified, no meaningful pattern of association with prevalence of latex fixation positivity is observed, except as already noted.

Table 6 indicates that there is no apparent association of prevalence of positive latex fixation tests with either serum uric acid or serum cholesterol. The only association seen is with age.

\section{Prevalence rates for rheumatoid arthritis}

Following completion of the field work and latex fixation tests the records of all respondents with any suggestion of rheumatoid arthritis were reviewed and an attempt made to establish the diagnosis of rheumatoid arthritis in conformity with the diagnostic criteria of the American Rheumatism Association. [7] It was possible to utilize only seven of the eleven diagnostic criteria since X-ray examination of the joints was not undertaken and it was not possible to examine the characteristics of the synovial fluid or obtain biopsies of the synovialis or subcutaneous nodules. The few cases that qualified as "classical" rheumatoid arthritis were included in the "definite" group. A diagnostic category labeled "questionable" was added in order to insure that individuals with only joint pain or tenderness, morning stiffness or a history of joint swelling would not be lost to follow-up.

Table 7. Prevalence (\%) of Rheumatoid arthritts by sex and by ciassification as to degree of diagnostic certainty. Persons 6 yr of age and older

\begin{tabular}{lccc}
\hline & \multicolumn{3}{c}{ Prevalence among } \\
\cline { 2 - 4 } $\begin{array}{l}\text { Degree of } \\
\text { diagnostic }\end{array}$ & $\begin{array}{c}3696 \\
\text { females } \\
\text { certainty }\end{array}$ & $\begin{array}{l}3511 \\
\text { males } \\
(\%)\end{array}$ & $\begin{array}{c}7207 \text { of } \\
\text { both sexes } \\
(\%)\end{array}$ \\
\hline "Definite" & 0.6 & 0.2 & 0.4 \\
"Probable" & 1.4 & 0.3 & 0.9 \\
"Possible" & 2.9 & 1.7 & 2.3 \\
"Questionable" & 2.5 & 1.3 & 1.9 \\
\hline Total & 7.4 & 3.5 & 5.5 \\
All degrees & & & \\
\hline
\end{tabular}

The estimated prevalence rates for subjects age $6 \mathrm{yr}$ and over are indicated in Table 7. The rate for "definite" disease for subjects of both sexes was 0.4 per cent. Somewhat higher rates were obtained for the less certain diagnostic categories-. 0.9 per cent for "probable", 2.3 per cent for "possible" and 1.9 per cent for "questionable" rheumatoid arthritis. The estimated prevalence rate for the total of all diagnostic categories was 5.5 per cent, 7.4 per cent for females and 3.5 per cent for males. Females exceeded males in all categories.

The estimated prevalence rates for rheumatoid arthritis for subjects age $16 \mathrm{yr}$ and over are presented in Table 8 to facilitate comparison with the reports of other investigations which have been limited to this age range. "Definite" rheumatoid arthritis was present in 0.7 per cent of the females and 0.3 per cent of the males, while the rates for total suspected rheumatoid arthritis were 10 per cent for females 
Table 8. Prevalence $(\%)$ of rheumatoid arthritis by SeX and Classification as to degree of diagnostic certainty. Ratios of female to male rates. Persons 16 yr of age and OLUEK

\begin{tabular}{lcccc}
\hline & \multicolumn{3}{c}{ Prevalence among } & \\
\cline { 2 - 4 } $\begin{array}{l}\text { Degrec of } \\
\text { diagnostic }\end{array}$ & $\begin{array}{c}2692 \\
\text { females } \\
(\%)\end{array}$ & $\begin{array}{c}2456 \\
\text { males } \\
(\%)\end{array}$ & $\begin{array}{c}5148 \text { of } \\
\text { both sexes } \\
(\%)\end{array}$ & $\begin{array}{c}\text { Ratio of } \\
\text { female : male } \\
\text { prevalence rates }\end{array}$ \\
\hline "Definite" & 0.7 & 0.3 & 0.5 & $2.3: 1$ \\
"Probable" & 1.9 & 0.4 & 1.2 & $4.8: 1$ \\
"Possible" & 4.0 & 2.4 & 3.2 & $1.7: 1$ \\
"Questionable" & 3.4 & 1.8 & 2.6 & $1.9: 1$ \\
\hline Total & 10.0 & 4.9 & 7.6 & $2.4: 1$ \\
\hline All categories & & & & \\
\hline
\end{tabular}

and 4.9 per cent for males. The female: male ratio for "definite" cases was 2.3:1 and for total suspected cases $2.4: 1$.

The age-sex specific prevalence rates for total suspected and "definite" rheumatoid arthritis (Fig. 7) show a rise with increasing age. Prevalence rates for "definite" disease were relatively low at all ages but showed a gradual rise for males from 0.44 per cent in the fourth decade to 0.79 per cent in the eighth decade and for females from 1.69 per cent in the fifth decade to 2.47 per cent in the eighth decade. Only one case of "definite" rheumatoid arthritis was found in the first three decades and that in a female in the 6-15 yr age group. A more pronounced increase in prevalence with age is apparent for "total suspected" rheumatoid arthritis. In the males this increase is interrupted by a decline in the seventh decade and in the females there is no further increase in the sixth, seventh and eighth decades.

\section{Prevalence rates for ankylosing spondylitis}

The diagnosis of ankylosing spondylitis was based on the presence of a compatible medical history and physical examination, occasionally with a history of previous diagnosis following X-ray studies of the low back region. Radiologic

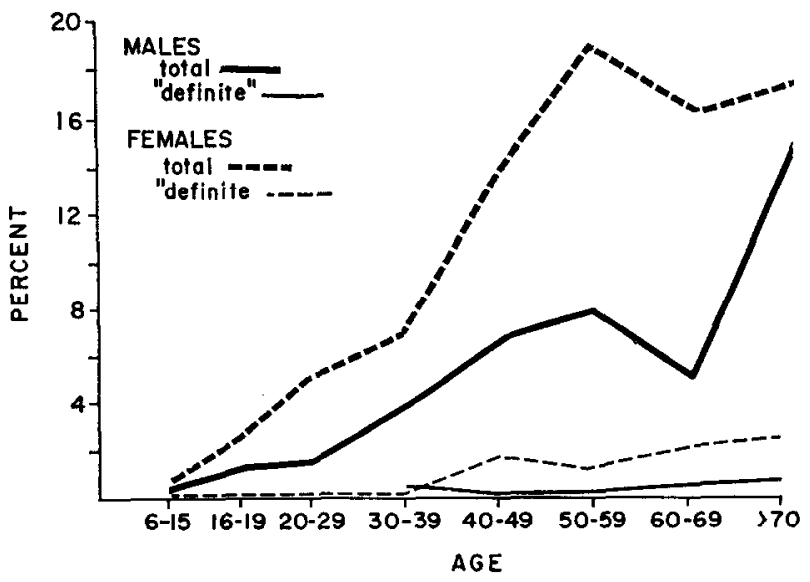

Fig. 7. Prevalence rates for rheumatoid arthritis. 
examination of the spine and sacroiliac joints was not undertaken in the present investigation.

A total of 16 respondents, 14 males and 2 females, were suspected of having this condition. The estimated prevalence rates for males and females are indicated in Table 9; the over-all rate for male subjects was 0.4 per cent and for females 0.05 per cent.

\section{Prevalence rates for osteoarthritis}

The diagnosis of osteoarthritis was made by the examining physician on the basis of the available medical history and the physical findings. The examiners were specifically asked to record the presence or absence of Heberden's nodes. Radiologic examinations were not made.

The age-sex specific prevalence rates for "probable" osteoarthritis are indicated in Table 10. This diagnosis was not recorded for any respondent under age 20 and for less than 1 per cent of subjects in the age range 20-39. For subjects aged 40-59 rates were 3-4 per cent for males and 8-9 per cent for females. In subjects aged 60 and over the rates rise markedly. In males 17 per cent were regarded as having the disease on the basis of the history and 20.3 per cent on the basis of examination, while the corresponding rates for females were 29.6 and 40.8 per cent. In Fig. 8 are illustrated the age-sex specific prevalence rates for Heberden's nodes, which also demonstratc a striking risc with increasing age.

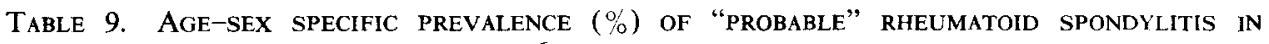
PERSONS 6 YR OF AGE AND OLDER

\begin{tabular}{|c|c|c|c|c|}
\hline \multirow{2}{*}{$\begin{array}{l}\text { Age group } \\
\text { in } y_{r}\end{array}$} & \multicolumn{2}{|c|}{ Number examined } & \multicolumn{2}{|c|}{$\begin{array}{c}\text { Prevalence of } \\
\text { spondylitis }\end{array}$} \\
\hline & Male & Female & Male & Female \\
\hline $6-19$ & $\begin{array}{l}1272 \\
\text { (1) }\end{array}$ & $\begin{array}{r}1247 \\
(0)\end{array}$ & 0.1 & 一 \\
\hline $20-39$ & $\begin{array}{r}1134 \\
(4)\end{array}$ & $\begin{array}{l}1290 \\
\text { (1) }\end{array}$ & 0.4 & 0.1 \\
\hline $40-59$ & $\begin{array}{l}800 \\
(8)\end{array}$ & $\begin{array}{l}801 \\
\text { (1) }\end{array}$ & 1.0 & 0.1 \\
\hline 60 or more & $\begin{array}{l}305 \\
(1)\end{array}$ & 358 & 0.3 & - \\
\hline $\begin{array}{l}\text { All ages } \\
16 \text { or more }\end{array}$ & $\begin{array}{l}3511 \\
\quad(14)\end{array}$ & $\begin{array}{r}3696 \\
(2)\end{array}$ & 0.4 & 0.05 \\
\hline
\end{tabular}

Prevalence rates for gout

The diagnosis of gout was based, insofar as possible, on the diagnostic criteria proposed by a sub-committee of the C.I.O.M.S. Symposium on the Epidemiology of Chronic Rheumatism, Rome, 1961. [8] The characteristics of the distribution of serum uric acid levels in this population have been previously reported. [9]

The age sex specific prevalence rates for probable gout in the 6000 persons having serum uric acid determinations are indicated in Table 11. This diagnosis was not recorded for any subject under age 20 , but was thereafter recorded for 24 respondents, 14 men and 10 women. The over-all prevalence rates were 0.5 per cent for males and 0.3 per cent for females, with highest rates of 1.3 per cent for males and 0.7 per cent for females being recorded for subjects aged 40-59. 
TABLE 10. AGE-SEX SPECIFIC PREVALENCE (\%) OF "PROBABLE" OSTEOARTHRItIS, Diagnosis By HISTORY AND BY EXAMTNATION*

\begin{tabular}{|c|c|c|c|c|c|c|}
\hline \multirow[b]{3}{*}{$\begin{array}{c}\text { Age group } \\
\text { in } y r\end{array}$} & \multirow{2}{*}{\multicolumn{2}{|c|}{ Number examined }} & \multicolumn{4}{|c|}{ Diagnosis by } \\
\hline & & & \multicolumn{2}{|c|}{ History } & \multicolumn{2}{|c|}{ Examination } \\
\hline & Males & Females & $\begin{array}{r}\text { Males } \\
(\%)\end{array}$ & $\begin{array}{c}\text { Females } \\
(\%)\end{array}$ & $\begin{array}{c}\text { Males } \\
(\%)\end{array}$ & $\begin{array}{c}\text { Females } \\
(\%)\end{array}$ \\
\hline $\begin{array}{l}\text { Less than } 20 \\
20-39 \\
40-59 \\
60 \text { or more }\end{array}$ & $\begin{array}{r}1999 \\
1134 \\
800 \\
305\end{array}$ & $\begin{array}{r}1954 \\
1290 \\
801 \\
358\end{array}$ & $\begin{array}{r}\overline{0.2} \\
3.4 \\
17.0\end{array}$ & $\begin{array}{r}- \\
0.4 \\
8.4 \\
29.6\end{array}$ & $\begin{array}{r}\overline{-} \\
4.0 \\
20.3\end{array}$ & $\begin{array}{r}\overline{0.2} \\
8.9 \\
40.8\end{array}$ \\
\hline All ages & 4238 & 4403 & 1.9 & 4.0 & 2.2 & 5.0 \\
\hline
\end{tabular}

*Based on all examined persons, all ages.

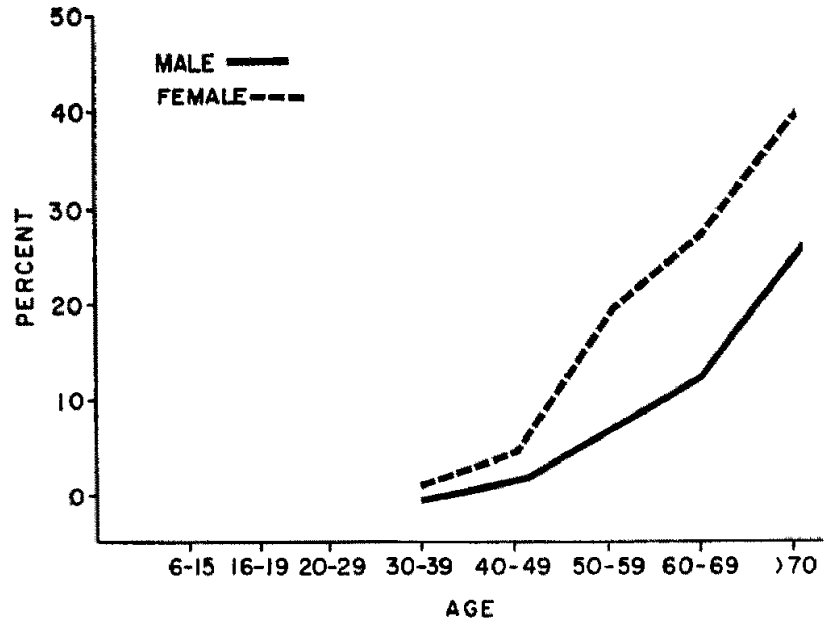

FIG. 8. Prevalence of Heberden's nodes.

Table 11. Age-SeX specific prevalence (\%) of "probable" gout in 6000 persons having SERUM URIC ACID DETERMINATIONS

\begin{tabular}{|c|c|c|c|c|}
\hline \multirow[b]{2}{*}{$\begin{array}{l}\text { Age group } \\
\text { in } y r\end{array}$} & \multicolumn{2}{|c|}{ Number examined } & \multicolumn{2}{|c|}{$\begin{array}{c}\text { Prevalence of } \\
\text { gout }\end{array}$} \\
\hline & Male & Female & Male & Female \\
\hline $4-19$ & $\begin{array}{l}1048 \\
(0)\end{array}$ & $\begin{array}{r}937 \\
(0)\end{array}$ & - & - \\
\hline $20-39$ & $\begin{array}{l}972 \\
(4)\end{array}$ & $\begin{array}{l}1085 \\
\text { (4) }\end{array}$ & 0.4 & 0.4 \\
\hline $40-59$ & $\begin{array}{l}690 \\
\text { (9) }\end{array}$ & 695 & 1.3 & 0.7 \\
\hline 60 or more & $\begin{array}{r}277 \\
\text { (1) }\end{array}$ & $\begin{array}{l}296 \\
\text { (1) }\end{array}$ & 0.4 & 0.3 \\
\hline $\begin{array}{l}\text { All ages } 4 \text { yr } \\
\text { or more }\end{array}$ & $\begin{array}{l}2987 \\
\text { (14) }\end{array}$ & $\begin{array}{l}3013 \\
(10)\end{array}$ & 0.5 & 0.3 \\
\hline
\end{tabular}

()$=$ number diagnosed as "probable". 
Prevalence rates for history of rheumatic fever or chorea and for rheumatic heart disease

The age-sex specific prevalence rates for a history of rheumatic fever or chorea, and for rheumatic heart disease, based on the findings at time of examination, are indicated in Table 12. Rheumatic fever and chorea were recorded with equal frequency for male and female subjects, the over-all prevalence rate for the former being 0.8 per cent and for the latter 0.1 per cent. A history of chorea was not recorded among the respondents under age 20 . Rheumatic heart disease was recorded in all age groups and was only slightly more frequent in the females, 0.6 per cent as compared to 0.4 per cent in males.

Table 12. Age-seX specific prevalence (\%) of “probable" rheumatic heart disease, HISTORY OF RHEUMATIC FEVER AND HISTORY OF CHOREA*

\begin{tabular}{|c|c|c|c|c|c|c|c|c|}
\hline \multirow{4}{*}{$\begin{array}{l}\text { Age group } \\
\text { in } \mathrm{yr}\end{array}$} & & & \multicolumn{6}{|c|}{ Prevalence $(\%)$ of: } \\
\hline & & & & & & Histo & $y$ of: & \\
\hline & \multicolumn{2}{|c|}{$\begin{array}{l}\text { Number } \\
\text { examined }\end{array}$} & \multicolumn{2}{|c|}{$\begin{array}{l}\text { Rheumatic heart } \\
\text { disease (Exam) }\end{array}$} & \multicolumn{2}{|c|}{$\begin{array}{l}\text { Rheumatic } \\
\text { fever }\end{array}$} & \multicolumn{2}{|c|}{ Chorea } \\
\hline & Males & Females & Males & Females & Males & Females & Males & Females \\
\hline $\begin{array}{l}\text { Less than } 20 \\
20-39 \\
40-59 \\
60 \text { or more }\end{array}$ & $\begin{array}{r}1999 \\
1134 \\
800 \\
305\end{array}$ & $\begin{array}{r}1954 \\
1290 \\
801 \\
358\end{array}$ & $\begin{array}{l}0.1 \\
0.4 \\
0.8 \\
0.7\end{array}$ & $\begin{array}{l}0.3 \\
0.6 \\
1.2 \\
0.2\end{array}$ & $\begin{array}{l}0.6 \\
0.9 \\
1.5 \\
0.3\end{array}$ & $\begin{array}{l}0.7 \\
1.0 \\
1.1 \\
0.5\end{array}$ & $\begin{array}{l}-\overline{0.3} \\
0.1 \\
-\end{array}$ & $\begin{array}{l}\overline{0.2} \\
0.4 \\
0.3\end{array}$ \\
\hline All ages & 4238 & 4403 & 0.4 & 0.6 & 0.8 & 0.8 & 0.1 & 0.1 \\
\hline
\end{tabular}

*Based on all examined persons, all ages.

\section{Historical information}

\section{I S C USSI O N}

Rheumatic complaints were elicited in a high proportion of the residents of Tecumseh, Michigan, approximately one-third of whom reported joint pain or aching while roughly one-sixth complained of each of the following: joint swelling, morning stiffness and past arthritis or rheumatism. These complaints occurred uncommonly in children but more frequently with advancing age.

It is of considerable interest to see how these questions served their intended purpose as a "screen" for the detection of rheumatoid arthritis. The use of a questionnaire for this purpose was described by RuBIN, Rosenbaum and CoBB $[5,6]$ who employed a Rheumatoid Arthritis Index based on the following three questions:

1. Have you ever had any arthritis or rheumatism?

2. Have you ever had swelling in any joints?

3. Do you wake up with any aching or stiffness in your muscles or joints?

A positive index, defined as a "yes" answer to all three questions, was reported by these authors in 65 per cent of clinically diagnosed cases of rheumatoid arthritis and in only 5 per cent of clinically non-rheumatoid cases. Of the more than 7000 Tecumseh respondents age 6 and over, 281 or 4 per cent answered "yes" to each of the three questions and thus had a positive index. Of this group almost 60 per cent had no supporting clinical evidence for rheumatoid arthritis. Of the 28 persons classified as having "definite" rheumatoid arthritis 75 per cent had a posi- 
tive index, and of the 61 persons classified as having "probable" rheumatoid arthritis 34 per cent had a positive index. Of all respondents 34.8 per cent answered "yes" to one or more of the questions. Of the 65.2 per cent who replied "no" to all questions, 99.6 per cent presented no clinical evidence of rheumatoid arthritis.

Thus, it would appear that these questions do serve a valuable purpose in that consistently negative replies are obtained with extreme rarity from subjects suspected of having rheumatoid arthritis. These results would suggest, however, that it would be unwise to limit the "screen" to those with positive replies to all questions (a positive index of rheumatoid arthritis) since a significant proportion of cases of definite or suspected rheumatoid arthritis would thereby be missed.

\section{Latex fixation tests}

The prevalence of latex test positivity, unlike that of clinical rheumatoid arthritis, was found to be equal in males and females. Rates were minimal in the childhood age group but thereafter rose progressively with advancing age to reach peak values in the 70-plus age group. In a population such as that of Tecumseh with its broad age range and low prevalence of rheumatoid arthritis, the latex fixation test is not an effective case-finding tool. Although it has a high specificity, as seen in Table 3, it has a low sensitivity. Two-thirds of the respondents with positive results presented no other evidence of rheumatoid arthritis. The possibility exists that in these individuals the presence of rheumatoid factor may represent the earliest manifestation of the disease, or select those subjects with a predisposition to later development of the disease. Only periodic re-evaluation of these persons will establish whether this is the case or not.

Only a minority of respondents with clinical evidence of rheumatoid arthritis had positive latex fixation tests. Of the total 399 subjects with suspected rheumatoid arthritis only 74 or 18 per cent had a positive test. Of those cases classified as "definite" 26 per cent had a positive latex test in comparison to approximately 85 per cent in "definite" cases in our clinical experience. The explanation of this discrepancy is not readily apparent, although one factor would seem to be the process of selection by which only patients with more severe diseases present themselves to an arthritis clinic.

The association of positive latex tests with certain other diagnoses, such as previous jaundice or infectious hepatitis. is of interest. In some instances, such as right heart failure and pulmonary emphysema, it is quite likely that the association is a secondary one based on the age distribution of the subjects. That this is probably also true of the relationship with blood pressure is suggested by the finding that the frequency of test positivity rises with increasing systolic levels in persons of $30 \mathrm{yr}$ or older, but not with increasing diastolic levels. Test positivity appeared to be unrelated to serum cholesterol concentration or serum uric acid.

\section{Comparison with results of others}

Differences in methodology and inter-observer variability make it difficult to compare results of epidemiologic studies of rheumatic diseases in different population groups. The use of diagnostic criteria reduces this difficulty but does not eliminate it completely. Despite this difficulty, certain comparisons can be made between results of the TCHS and other comparable investigations. 
Most population studies are in agreement in suggesting a high prevalence of rheumatic complaints. Prevalence rates for a history of joint pain, joint swelling and morning stiffness in Tecumseh are in reasonable agreement with those reported for Pittsburgh by CoBb and Rosenbaum, [11] especially when it is recalled that the Tecumseh figures are based on subjects aged 6 yr and over as compared to age 15 and over. The prevalence rates for morning stiffness in the Tecumseh population correspond closely to those reported from Heinola. [12] In the Health Examination Survey [18] in this country, as in the TCHS, morning stiffness increased in prevalence with advancing age (Table 13).

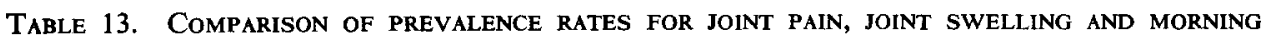
STIFFNESS IN DIFFERENT STUDIES

\begin{tabular}{ccc}
\hline $\begin{array}{c}\text { Joint pain } \\
\text { Pittsburgh [11] } \\
\text { Tecumseh }\end{array}$ & $\begin{array}{c}\text { Males } \\
48\end{array}$ & $\begin{array}{c}\text { Females } \\
41 \\
\end{array}$ \\
\hline Joint swelling & 34.4 & 34.8 \\
Pittsburgh [11] & Males & Females \\
Tecumseh & 12 & 22 \\
& 13.4 & 16.9 \\
\hline Morning stiffness & Males & Females \\
Pittsburgh [11] & 24 & 33 \\
Tecumseh & 15.7 & 19.5 \\
Heinola [12] & 14 & 23 \\
H.E.S. [18] & 22.1 & 32.2 \\
\hline
\end{tabular}

Age of respondents was $18 \mathrm{yr}$ and over in the Health Examination Survey, $15 \mathrm{yr}$ and over in the Pittsburgh and Heinola studies and $6 \mathrm{yr}$ and over in the Tecumseh study.

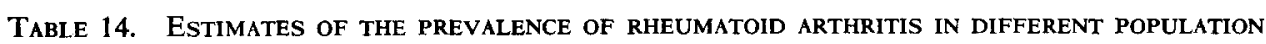
STUDIES

\begin{tabular}{|c|c|c|c|c|c|c|c|}
\hline & \multicolumn{3}{|c|}{ Definite plus probable } & \multicolumn{3}{|c|}{ Definite } & \\
\hline & Males & Females & Both & Males & Females & Both & \\
\hline Wensleydale and Leigh & 2.5 & 6.0 & 4.3 & 0.47 & 1.6 & 1.07 & \\
\hline $\begin{array}{l}\text { Wales: Rhonda Fach [14] } \\
\text { Yale of Glamorgan }\end{array}$ & 1.1 & 1.8 & 1.4 & 0.7 & 0.6 & 0.75 & \\
\hline $\begin{array}{l}\text { Vale of Glamorgan } \\
\end{array}$ & 27 & 5.6 & 415 & & & & \\
\hline Heinola, Finland [12] & 3.9 & 10.1 & 7.5 & 1.3 & 4.2 & 3.0 & \\
\hline Pittsburgh [15] & 0.6 & 4.7 & 2.7 & & & 0.7 & \\
\hline Netherlands [19] & 0.4 & 1.0 & 0.7 & & & & \\
\hline $\begin{array}{l}\text { Guaynabo, Puerto Rico [16] } \\
\text { American Indian. }\end{array}$ & 0.32 & 1.2 & 0.92 & 0.16 & 0.4 & 0.34 & \\
\hline $\begin{array}{l}\text { American Indian: } \\
\text { Pima }[30,36] \\
\text { Blackfeet }[30,36]\end{array}$ & & & $\begin{array}{l}5.4 \\
4.1\end{array}$ & & & $\begin{array}{l}1.7 \\
1.2\end{array}$ & 30 and over \\
\hline Haida Indian [17] & 1.7 & 2.0 & 1.8 & 0.4 & 1.5 & 0.9 & \\
\hline $\begin{array}{l}\text { Tecumseh } \\
\text { Health Examination Survey, }\end{array}$ & 0.7 & 2.6 & 1.6 & 0.3 & 0.7 & 0.5 & 15 and over \\
\hline $\begin{array}{l}\text { U.S. [18] } \\
\text { Japan: Hiroshima and }\end{array}$ & 1.7 & 4.6 & 3.2 & 0.5 & 1.4 & 1.0 & 18 and over \\
\hline Nagasaki [35] & & & & 0.19 & 0.45 & 0.35 & 15 and over \\
\hline
\end{tabular}


Estimates of the prevalence of definite plus classical rheumatoid arthritis range from 0.34 per cent in Guaynabo, Puerto Rico [16] to 3.0 per cent in Heinola, Finland, [12] while those for probable, definite and classical disease vary from 0.7 per cent in the Netherlands to 7.5 per cent in Heinola (Table 14). With the exception of the American Indian Study [30] all of the reported investigations disclosed a higher prevalence in women than in men, as would be expected on the basis of clinical experience. Similarly, they show an increase in prevalence rates with advancing age. In the oldest age groups the prevalence rates rise to their highest levels, but in all studies relatively few subjects are included in these older groups.

The prevalence data for latex test positivity in the TCHS are in general agreement with those obtained with other serologic tests for rheumatoid factor in other population studies (Table 15). Such studies are also in agreement in suggesting:

(1) that prevalence rates for rheumatoid factor seropositivity are approximately the same for males and females, $[14,18,25,26]$

(2) prevalence rates are lowest in childhood, and show a progressive rise with advancing age, $[18,25-28]$

(3) a majority of respondents with positive rheumatoid factor tests have no supporting evidence of rheumatoid arthritis, [25] and

(4) the prevalence of positive tests in those respondents with clinical evidence of rheumatoid arthritis is lower than that encountered in a clinic or hospital setting. $[13,18,27,29]$

Table 15. Prevalence of positive serologic tests for RHeumatold factor IN DifFerent POPULATION STUDIES

\begin{tabular}{llcr}
\hline \multicolumn{1}{c}{ Population studied } & Test employed & Male & Female \\
\hline H.E.S. U.S.A. [18] & Bentonite flocc. & 3.41 & 3.48 \\
Leigh, Wensleydale [13] & S.S.C-A.T. & 4.0 & 5.0 \\
Seven European Comm. [28] & SCAT & 3.7 & 4.4 \\
& Bentonite & 4.0 & 4.0 \\
Haida Indian [17] & SCAT & 1.2 & 3.5 \\
Tecumseh & Latex fixation & 3.4 & 3.3 \\
\hline
\end{tabular}

Gout has proven to be so uncommon in most population studies that significant numbers of cases are difficult to obtain. Thus, POPERT and Hewirt [31] found no gout among 436 male and 475 female subjects in Wensleydale and only two cases, both in males, among 288 subjects ages 55-64 in Leigh, England. Higher rates are reported for Framingham, Mass., [32] but these are based on repeated examinations over a period of $10 \mathrm{yr}$. In subjects $40 \mathrm{yr}$ of age or more, the cumulative prevalence rate of gout was 2.8 per cent in males and 0.4 per cent in females. It was further shown that the risk of developing gout in this population rose with increasing degrees of hyperuricemia. Considerably higher point prevalence figures for gout have been reported for certain racial groups, including Filipino males living in the Hawaiian Islands [37] and Pacific Northwest [38] and Maori natives in New Zealand. [33] In the latter study the prevalence of gout among the Whanau-a-apanu tribe was reported to be 8.2 per cent for adult males and 1.6 per cent for females. Prevalence rates for males of the Arawa tribe were 6.0 per cent as compared to 0.7 per cent for non-Maori males in Rotowa. 
Like gout, ankylosing spondylitis has been observed with low frequency in most population studies. WeST [20] estimated the prevalence of the disease in Bristol, England to be 0.05 per cent. Reported prevalence rates include values of 0.08 per cent from the Netherlands, [21] 0.19 per cent from Heinda, Finland, [22] 0.5 per cent from Leigh, England, [23] and 0.3 per cent from a random population sample age $15 \mathrm{yr}$ and over in Great Britain. [24] The prevalence estimated in the TCHS, 0.22 per cent, corresponds reasonably well with these other figures. In a population survey of the Haida Indians living in Western Canada a higher, and as yet unexplained, prevalence rate of 2.3 per cent was reported.

\section{S U M M A R Y}

Over 90 per cent of the more than 9000 residents of Tecumseh, Michigan participated in a program of comprehensive health examinations in 1959-60. Included in the examination were inquiries regarding rheumatic symptoms, physical examination of the spine and peripheral joints, and the latex fixation test for rheumatoid factor and serum uric acid measurement.

Joint pain or aching, joint swelling, morning stiffness, and past arthritis or rheumatism were common complaints, occurring in one-eighth to one-third of the population age $6 \mathrm{yr}$ and over. The age-sex specific prevalence rates for each of these historical items rose with increasing age. Male and female rates were quite similar during the first four decades of life, but thereafter female rates were somewhat higher.

The prevalence of positive latex fixation tests for rheumatoid factor was essentially the same for male and female subjects, 3.4 per cent for males and 3.35 per cent for females. The rates rose progressively from approximately one per cent in the 6-16 yr age group to almost 14 per cent for males and 9.4 per cent for females in the oldest age groups. The latex fixation test performed poorly as a case detection tool, only one-third of those respondents with positive tests having any other evidence to suggest a diagnosis of rheumatoid arthritis. Relatively high rates of latex positively occurred in individuals with a history of jaundice or infectious hepatitis and in those with evidence of emphysema or right heart failure. None of the respondents with psoriasis or pregnancy at the time of examination had positive latex tests. The prevalence of latex positivity showed a rise with increasing systolic blood pressure in persons over $30 \mathrm{yr}$ of age, but appeared to be unrelated to diastolic blood pressure, serum cholesterol or serum uric acid.

Prevalence rates for "definite" rheumatoid arthritis, based on the diagnostic criteria proposed by the American Rheumatism Association, were 0.4 per cent for all subjects age $6 \mathrm{yr}$ and over and 0.5 per cent for all subjects age $16 \mathrm{yr}$ and over. Prevalence rates for "definite" plus "probable" rheumatoid arthritis were 1.3 per cent in the age group $6 \mathrm{yr}$ and over and 1.7 per cent in the age group $16 \mathrm{yr}$ and over. In all diagnostic categories prevalence rates for females exceeded those for males. In the age group $16 \mathrm{yr}$ and over the female to male ratio was 2.3:1 for "definite" disease and 2.4:1 for total suspected cases of rheumatoid arthritis. The prevalence rates for rheumatoid arthritis rose with increasing age; rates for "definite" disease rose from 0.44 per cent in the fourth decade to 0.79 per cent in the eighth decade for males and from 1.69 per cent in the fifth decade to 2.47 per cent in the eighth decade for females. 
The over-all prevalence rates for suspected ankylosing spondylitis, not confirmed by X-ray examination of the spine or sacroiliac joints, were 0.4 per cent for males and 0.05 per cent for females age $6 \mathrm{yr}$ and over.

Prevalence rates for osteoarthritis, diagnosed on the basis of physical rather than radiological examination were 2.2 per cent for males and 5.0 per cent for females age $6 \mathrm{yr}$ and over. Rates were highest in the older age groups, being 20.3 per cent for males and 40.8 per cent for females in the age group $60 \mathrm{yr}$ and over. The prevalence of Heberden's nodes was greater in female than in male respondents and demonstrated a similar rise with increasing age.

The prevalence of "probable" gout, based on available clinical information was 0.5 per cent for male and 0.3 per cent for female subjects age $4 \mathrm{yr}$ and over having serum uric acid determinations. The highest rates were observed in subjects in the age range $40-59 \mathrm{yr}$.

The prevalence rates for a history of rheumatic fever and/or chorea were similar for male and female subjects age $6 \mathrm{yr}$ and over, 0.8 per cent in the case of rheumatic fever and 0.1 per cent in the case of chorea. A history of chorea was not obtained among respondents under age 20. Physical evidence of rheumatic heart disease was recorded in all age groups and was slightly more prevalent in females. 0.6 per cent as compared to 0.4 per cent in males.

Comparisons of the results of this investigation with those of other population studies have bcen made although the interpretation of any differences or similarities is inherently limited by methodological problems and observer variation.

\section{A D DE N D U M}

Since completion of the above investigations the population of Tecumseh has been re-examined. These subsequent observations, which include $\mathrm{X}$-ray examinations of the cervical spine and hands and wrists, will supplement and amplify the present data.

\section{R E F E R E N C ES}

1. Epstein, F. H.: An epidemiological study in a total community. The Tccumsch Project, Univ. Mich. med. Bull. 26, 307, 1961.

2. Francis, T., Jr.: Aspects of the Tecumseh Study, Publ. Hith Rep., Wash. 76, 963, 1961.

3. Liddle, L., Seegmiller, J. E. and LASTER, L.: The enzymatic spectrophotometric method for determination of uric acid, J. Lab. clin. Med. 54, 903, 1959.

4. Singer, J. M. and Plotz, C. M.: The latex fixation test. I. Application to the serological diagnosis of rheumatoid arthritis, Am.J.Med. 21, 888, 1956.

5. Rubin, T., Rosenbaum, J. and Coвb, J.: The use of interview data for the detection of associations in field studies, J.chron. Dis. 4, 253, 1956.

6. KING, S. and CoBB, S.: Psychosocial factors in the epidemiology of rheumatoid arthritis, J. chron. Dis. 7, 466, 1958.

7. Ropes, M. W., Bennett, G. A., Cobb, S., Jacox, R. and Jessar, R. A.: 1958 revision of diagnostic criteria for rheumatoid arthritis, Bull. rheum. Dis. 9, 175, 1958.

8. The epidemiology of chronic rheumatism, ed. KeLlGREN, J. H., JEFFREY, M. R. and Ball, J. F. A. Davis, Philadelphia, pp. 295-297, 1963.

9. Mikxelsen, W. M., Dodge, H. J. and Valkenburg, H.: The distribution of serum uric acid values in a population unselected as to gout or hyperuricemia, Tecumseh, Michigan, 1959-1960, Am. J. Med. 39, 242, 1965.

10. Burch, T. A., O'Brien, W. M. and Bunim, J. J. : Family and genetic studies of rheumatoid arthritis and rheumatoid factor in Blackfeet Indians, Am. J. publ. Hlth 54, 1184, 1964.

11. CobB, S. and Rosenbaum, J.: A comparison of specific symptom data obtained by nonmedical interviewers and by physicians, J. chron. Dis. 4, 245, 1965. 
12. LaINe, V. A. I.: Rheumatic complaints in an urban population in Finland, Acta rheum. scand. 8, 81, 1962.

13. Lawrence, J. S.: Prevalence of rheumatoid arthritis, Ann. rheum. Dis. 20, 11, 1961.

14. Miall, W. E., Ball, J. and Kellgren, J. H.: Prevalence of rheumatoid arthritis in urban and rural populations in South Wales, Ann. rheum. Dis. 17, 263, 1958.

15. Cobb, S., Warren, J. E., Merchant, W. R. and Thompson, D. J.: An estimate of the prevalence of rheumatoid arthritis, J. chron. Dis. 5, 636, 1957.

16. Méndez-Bryan, R., González-Alcover, R. and Roger, L.: Rheumatoid arthritis: prevalence in a tropical area, Arth. Rheum. 7, 171, 1964.

17. Gofton, J. P., Robinson, H. S. and Price, G. E.: A study of rheumatic disease in a Canadian Indian population, Ann. rheum. Dis. 23, 364, 1964.

18. Engel, A., Roberts, J. and Burch, T. A.: Rheumatoid arthritis in adults. United States. 1960-1962. Vital and Health Statistics. PHS Pub. No. 1000-Series 11-No. 17. Public Health Service. Washington. U.S. Government Printing Office, September 1966.

19. DEGRAAFF, R.: Rheumatoid arthritis in the Netherlands. Its prevalence and social aspects. Proceedings of the ISRA Symposium on the Social Aspects of Chronic Rheumatic Joint Affections Especially Rheumatoid Arthritis, Excerpta Med. International Congress. Series, No. 23, 13-14 October, p. 7, 1959.

20. West, H. F.: The aetiology of ankylosing spondylitis, Amn. rheum. Dis. 8, 143, 1949.

21. deBlecourt, J. J., Polman, A. and deBlecourt-Meindersma, T.: Hereditary factors in rheumatoid arthritis and ankylosing spondylitis, Ann. rheum. Dis. 20, 215, 1961.

22. Julkunen, H.: Rheumatoid spondylitis; clinical and laboratory study of 149 cases compared with 182 cases of rheumatoid arthritis, Acta rheum. scand. 8, Supp. 4, 1962.

23. KelLgkeN, J. H. and Lawrence, J. S.: Rheumatoid arthritis in a population sample, $A n n$. rhoum. Dis. 15, 1, 1956.

24. AnSell, B. M., Bywaters, E. G. L. and Lawrence, J. S.: A family study in Still's disease, Ann. rheum. Dis. 21, 243, 1962.

25. Ball, J. and LAWrence, J. S.: Epidemiology of the sheep cell agglutination test, Ann. rheum. Dis. 20, 235, 1961.

26. Waller, M., Toone, E. C., Vaughan, E. and Curry, N.: Study of rheumatoid factor in a normal population, Arth. Rheum. 7, 513, 1964.

27. Aho, K., Julkunen, H., Laine, V., Ripatti, N. and Wager, O.: Clinical evaluation of the serological tests in rheumatoid arthritis. I. Normal series collected by random sampling, Acta rheum. scand. 7, 201, 1961.

28. Lawrence, J. S., Laine, J. A. I. and deGraaff, R.: The epidemiology of rheumatoid arthritis in Northern Europe, Proc. R. Soc. Med. 54, 454, 1961.

29. Wager, O., Ripatti, N., Laine, V., Julkunen, H. and Aho, K.: Clinical evaluation of the scrological tests in rheumatoid arthritis. II. Hospital serics of paticnts with definitc rheumatoid arthritis, Acta. rheum. scand. 7, 209, 1961.

30. Bunim, J. J., Burch, T. A. and O'Brien, W. M.: Influence of genetic and environmental factors on the occurrence of rheumatoid arthritis and rheumatoid factor in American Indians, Bull. rheum. Dis. 15, 349, 1964.

31. Popert, A. J. and Hewitt, J. V.: Gout and hyperuricemia in rural and urban populations, Ann. rheum. Dis. 21, 154, 1962.

32. Hall, A. P.: Discussion, in Proc. of Conference on Gout and Purine Metabolism, Arth. Rheum. 8, 643, 1965.

33. Lennane, G. A. Q., Rose, B. S. and Isdale, I. C.: Gout in the Maori, Ann. rheum. Dis. 19, $120,1960$.

34. Robinson, H. S., Gofton, J. P. and Price, G. E.: A study of rheumatic disease in a Canadian Indian population, Ann. rheum. Dis. 22, 232, 1963.

35. Wood, J. W., Kato, H., Johnson, K. G., Uda, Y., Russell, W. J. and Duff, I. F.: Rheumatoid arthritis in Hiroshima and Nagasaki, Japan. Prevalence, incidence and clinical characteristics, in preparation.

36. Burch, T. A., O’Brien, W. M., Lawrence, J. S., Bennett, P. H. and Bunim, J. J.: A comparison of the prevalence of rheumatoid arthritis (R.A.) and rheumatoid factor (R.F.) in Indian tribes living in Montana mountains and in Arizona desert (abstract), Arth. Rheum. 6, 765, 1963.

37. Stevermann, N. and Farias, A. H.: Hyperuricemia in Filipinos, Hawaii med. J. 20, 151, 1960.

38. Decker, J. L. and Lane, J. J., Jr.: Gouty arthritis in Filipinos, N.E.M.J. 261, 805, 1959. 